\title{
MOTIVASI BELAJAR DAN NILAI INDEKS PRESTASI MAHASISWA AKADEMI KEPERAWATAN ADI HUSADA SURABAYA
}

\author{
LUDY HAMMAMI HANDOJO, MARIA SUMIYENTA NUWA, IRAWATI MARGA \\ AKADEMI KEPERAWATAN ADI HUSADA \\ ludy.handojo@gmail.com
}

\begin{abstract}
ABSTRAK
Motivasi adalah salah satu dari banyak hal yang dijadikan suatu batas kesuksesan seseorang dalam belajar. Tanpa adanya motivasi maka sangatah sulit bagi seseorang untuk mencapai prestasi yang optimal. Tujuan dari penelitian ini adalah untuk mengetahui adanya hubungan antara motivasi belajar dengan nilai indeks prestasi. Desain penelitian yang digunakan adalah korelasi dengan pendekatan cross sectional. Populasi dalam penelitian ini adalah 90 mahasiswa Akademi Keperawatan Adi Husada Surabaya, dengan jumlah sampel sebesar 67 responden yang memenuhi kriteria inklusi. Teknik sampling yang digunakan simple random sampling. Pengumpulan data menggunakan kuesioner untuk mengukur variable motivasi belajar dan untuk melihat nilai indeks prestasi yang telah diraih oleh mahasiswa selama satu semester dilakukan secara observasi. Hasil uji statistik menunjukkan $\mathrm{p}=0.00(\alpha<0.05)$ dan $\mathrm{r}=0.853$ sehingga terdapat hubungan yang kuat antara motivasi belajar dengan nilai indeks prestasi. Motivasi belajar yang baik harus dapat ditimbulkan agar mahasiswa mampu melakukan proses pembelajaran dengna mudah dan dapat bersaing secara sehat dalam mepertahankan nilai-nilai yang telah diraih dalam setiap semester.
\end{abstract}

Kata kunci: motivasi belajar, nilai indeks prestasi.

\begin{abstract}
Motivation is one of the many things that made a limit a person's success in learning. Without the motivation it is difficult for a person to achieve optimal performance. The aim of this study was to determine the relationship between learning motivation and achievement index value. The study design used is a correlation with cross sectional approach. The population in this study were 90 students of the Academy of Nursing Adi Husada Surabaya, with a sample size of 67 respondents who met the inclusion criteria. The sampling technique used simple random sampling. Collecting data using questionnaires to measure variables of motivation to learn and to see the index value achievements that have been attained by students during a semester is done by observation. Statistical analysis showed $p=0.00(\alpha<0,05)$ and $r=0853$ so that there is a strong relationship between learning motivation and achievement index value. Motivation to learn that both must be generated so that students are able to make the learning process easy and dengna can compete fairly in mepertahankan values that have been achieved in each semester.
\end{abstract}

Keywords: learning motivation, grade point index 


\section{PENDAHULUAN}

Selama dalam bangku pendidikan, belajar merupakan peranan utama yang penting dalam menunjang suatu nilai untuk agar lebih mudah melangkah dalam bidang selanjutnya. Motivasi memiliki peranan penting terhadap pencapaian hasil belajar yang maksimal. Motivasi seringkali disamakan dengan dorongan. Dorongan atau tenaga tersebut merupakan suatu gerakan jiwa dan jasmani untuk berbuat sesuatu, sehingga motif tersebut merupakan driving force yang menggerakkan manusa untuk bertingkah laku dan perbuatan itu mempunyai tujuan tertentu. 1 Namun, pada kenyatannya, masih didapatkan motivasi yang rendah dalam diri mahasiswa untuk belajar.

Penelitian yang dilakukan oleh Wasty Soemanto (2003) hasilnya menyebutkan bahwa pengenalan seseorang terhadap hasil belajarnya selama ini merupakan hal yang penting, karena dapat digunakan sebagai acuan atau parameter mengenai usaha belajar yang selama ini telah dilakukan. ${ }^{8}$ Motivasi merupakan pemberian atau penimbulan motif atau dapat pula di artikan sebagai hal atau keadaan menjadi motif. Jadi motivasi adalah sesuatu yang menimbulkan semangat atau dorongan kerja. Sehingga dengan adanya dorongan yang menimbulkan semangat dalam diri indivdu dapat meningkatkan pula kinerja serta proses berpikir untuk mau dan mampu melakukan tindakan yang poistif dan bermanfaat. Semakin tinggi motivasi belajar yang dimiliki oleh seseorang, maka akan semakin baik hasil yang akan didapatkan.

Seperti halnya keadaaan yang ada pada mahasiswa Akademi Keperawatan Adi Husada Surabaya. Terdapat berbagai alasan yang diungkapkan dalam belajar di akademi ini, antara lain: pilihan sendiri atau pribadi karena sudah menjadi cita- citanya, kemudian merupakan pilihan terakhir dari beberapa jurusan yang dipilih dan ingin segera bekerja setelah lulus, dan yang terakhir adalah pilihan atau paksaan dari orang lain. Sehingga motivasi yang dimilikipun berbeda antara satu dengan yang lain. ${ }^{3}$

Dari uraian tersebut diatas, maka dapat dirumuskan masalah sebagai berikut: apakah terdapat hubungan antara dengan nilai indeks prestasi mahasiswa di Akademi Keperawatan Adi Husada Surabaya.

Penelitian ini bertujuan untuk mengetahui adanya hubungan antara motivasi belajar dengan nilai indeks prestasi mahasiswa di Akademi Keperawatan Adi Husada Surabaya.

Hasil dari penelitian ini diharapkan dapat memberikan informasi mengenai adanya hubungan antara motivasi belajar dengan nilai indeks prestasi, serta dapat meningkatkan keadaran terhadap mahasiswa bahwa motivasi berperan penting dalam mempengaruhi tercapainya hasil kerja yang memuaskan.

\section{METODE PENELITIAN}

Jenis penelitian yang digunakan adalah analitis dengan desain penelitian cross sectional. Penelitian ini bertujuan untuk mengidentifikasi korelasi antara motivasi belajar dengan nilai indeks prestasi.

Populasi target penelitian adalah mahasiswa Akademi Keperawatan Adi Husada tingkat I A dan I B yang berjumlah sebanyak 90 orang. Dengan jumlah sampel yang didapatkan dari hasil perhitungan sebesar 67 responden.

Teknik pengambilan sampel menggunakan teknik simple random sampling, yaitu memilih sampel secara acak oleh peneliti. Data responden berasal dari data presensi di Akademi Keperawatan Adi Husada Surabaya.

Metode pengumpulan data yang digunakan dalam penelitian ini berupa kuesioner dan observasi. Kuesioner yang diberikan kepada responden bertujuan untuk mengetahui dan mengukur tingkat motivasi yang dimiliki oleh setiap responden, dan observasi dilakukan untuk melihat nilai indeks prestasi yang telah dicapai oleh setiap responden dalam satu semester.

Data yang diperoleh akan dianalisis dengan uji Spearman Rank Test dengan $\alpha<0.05$.

\section{HASIL DAN PEMBAHASAN Data Umum}

Penelitian ini dilaksanakan di ruang kelas Anggrek I dan II Akademi Keperawatan Adi Husada Surabaya pada mahasiswa tingkat I kelas 1A dan 1B. Subyek penelitian yang memenuhi kriteria inklusi serta menyetujui untuk berpartisipasi dalam penelitian sebanyak 67 orang. 
Tabel 1 Karakteristik reponden

\begin{tabular}{llrc}
\hline No & Karakteristik & n & \% \\
\hline \multirow{2}{*}{1} & Jenis Kelamin & & \\
\cline { 2 - 4 } & Laki-laki & 12 & 18 \\
\cline { 2 - 4 } & Perempuan & 55 & 82 \\
\hline 2 & Usia & 64 & 96 \\
\cline { 2 - 4 } & $18-20$ & 3 & 4 \\
\cline { 2 - 4 } 3 & $21-23$ & & \\
& Latar Belakang & & \\
\cline { 2 - 4 } & Pendidikan & 45 & 67 \\
\cline { 2 - 4 } & SMA & 22 & 33 \\
\cline { 2 - 4 } & SMK & & \\
\hline
\end{tabular}

Dari tabel 1 menunjukkan sebagian besar responden adalah perempuan yaitu 55 mahasiswa (82\%), berusia 18-20 tahun yaitu 64 mahasiswa (96\%) dan berlatar pendidikan SMA yaitu 45 mahasiswa (67\%)

\section{Data Khusus}

Tabel $2 \begin{aligned} & \text { Distribusi } \\ & \text { Responden }\end{aligned}$ Motivasi Belajar

\begin{tabular}{ccr}
\hline Tingkat Motivasi & n & \multicolumn{1}{c}{$\%$} \\
\hline Baik & 11 & 16 \\
Cukup & 43 & 64 \\
Kurang & 13 & 20 \\
Jumlah & 67 & 100 \\
\hline
\end{tabular}

Tabel 2 menunjukkan sebagian besar mahasiswa memiliki motivasi yan cukup yaitu 43 responden $(64 \%)$.

Tabel 3. Distribusi Nilai Indeks Prestasi Responden

\begin{tabular}{crcr}
\hline Kategori & Nilai IP & n & \% \\
\hline Memuaskan & $2,00-2,75$ & 13 & 19 \\
Sangat & $2,75-3,50$ & 44 & 66 \\
Memuaskan & & & \\
Dengan Pujian & $3,50-4,00$ & 10 & 15 \\
Jumlah & & 67 & 100 \\
\hline
\end{tabular}

Dari tabel 3 menunjukkan sebagian besar responden memiliki kategori sangat memuaskan yaitu 44 mahasiswa (66\%).

Hasil statistik dengan uji Spearman's Rho menunjukkan $\mathrm{p}=0.00$ (nilai signifikansi $\alpha<0.05)$ dan $r=0.853$. Sehingga dapat disimpulkan ada hubungan yang bersifat kuat antara motivasi belajar dan nilai indeks prestasi mahasiswa.

\section{PEMBAHASAN}

Hasil penelitian ini menunjukkan bahwa seseorang dengan tingkat motivasi yang baik mendapatkan nilai indeks prestasi dalam kategori sangat memuaskan, yaitu dengan nilai 2,75-3,50 bahkan dapat juga masuk dalam kategori dengan pujian, atau yang biasa disebut dengan Cum Laude yang nilainya sebesar 3,50-4,00. Maka hal ini sesuai dengan yang pernah di ungkapkan oleh peneliti sebelumnya bahwa semakin tinggi atau semakin baik motivasi yang dimiliki oleh seseorang, maka semakin baik pula hasil kerja dan nilai yang ia raih. ${ }^{1}$

Selain itu hasil penelitian ini juga sesuai dengan teori yang diungkapkan oleh Sutrisno (2009) bahwa motif yang ada dalam diri seseorang dapat mendorong orang tersubut melakukan sesuatu untuk meraih tujuan tertentu. Mahasiswa yang memiliki motivasi yang kurang dalam dirinya hanya mendapatkan nilai indeks prestasi dalam kategori memuaskan yaitu dengan cakupan nilai antara 2,00-2,75. Hal ini didasari oleh adanya paksaan dari orang lain terutama pihak keluarga. Sehingga hasil yang didapatkanpun kurang memuaskan. Hal ini saling berkaitan karena motif dalam diri seseorang juga dipengaruhi oleh faktor-faktor yang salah satunya adalah bakat atau intelegensi diri. Mahasiswa yang mengalami paksaan tersebut merasa bahwa dirinya tidak mempunyai bakat dalam bidang yang diambil saat ini, sehingga motivasi belajar yang dimiliki tidak sebesar mahasiswa lain yang mempunyai motivasi dalam kategori yang baik ataupun cukup. ${ }^{4}$ Selain itu, lingkungan serta teman-teman disekitar kampus pun ikut berpengaruh dalam terbentuknya motivasi belajar yang baik bagi mahasiswa yang kurang mampu mengembangkan dirinya dalam bidang kesehatan ini. Selain itu motivasi yang kurang didapatkan juga karena adanya fasilitas praktikum yang kurang mendukung, seperti alat perga yang fungsinya telah berkurang sehingga mahasiswa kurang berminat untuk melakukan praktikum tersebut. Hal inilah yang juga menyebabkan mahasiswa tidak terlatih dalam belajar baik dalam meningkatkan softskill maupun hardskill. Hal ini juga sesuai dengan teori Wasty Soemanto dan Slamet (2003) bahwa faktor situasi dan lingkungan yang didalamnya termasuk fasilitas-fasilitas pendukung pembelajaran dapat mempengaruhi minat, harapan serta motif dalam diri siswa untuk mau belajar dan mengembangkan kemampuannya. ${ }^{6}$

Memunculkan motivasi belajar dalam diri seseorang juga perlu dilakukan pendekatan dalam proses belajarnya. Komunikasi yang baik yang dapat terjalin dalam pergaulan sehari-hari yang positif 
mampu meningkatkan motivasi seseorang dalam melakukan proses belajar karena ia akan merasa mendapat dukungan serta kelompok yang dapat membantu ketika ia tidak mengerti. Sehingga selain ini menjadi perhatian antarteman sebaya, hal ini juga menjadi perhatian bagi para dosen yang mengajar. Dosen yang aktif dan dapat mengerti kondisi mahasiswa, dapat memberikan dukungan tersendiri dalam diri mahasiswa tersebut untuk terus akif dan belajar serta bertanya mengenai apa yang belum dimengerti. Sehingga semakin tinggi motif dalam diri mahasiswa, maka mahasiswa dapat memacu kemampuannya dalam meraih nilai yang tinggi. ${ }^{8}$

Motivasi belajar yang baik harus dapat ditimbulkan agar mahasiswa mampu melakukan proses pembelajaran dengna mudah dan dapat bersaing secara sehat dalam mepertahankan nilai-nilai yang telah diraih dalam setiap semester. ${ }^{5}$ Nilai indeks prestasi yang tinggi dapat mempengaruhi proses berpikir seseorang dan lapangan kerja yang terbuka bagi mereka serta kesempatan besar yang dapat digunakan untuk seperti bersekolah lagi, mengajar bahkan dapat membuka lapangan kerja bagi orang lain.

\section{SIMPULAN}

1. Motivasi belajar yang dimiliki oleh mahasiswa Akademi Keperawatan Adi Husada tergolong dalam kategori cukup,

2. Sebagian besar mahasiswa Akademi Keperawatan Adi Husada Surabaya memiliki nilai indeks prestasi dalam kategori sangat memuaskan dengan nilai antara 2,75-3,50

3. Terdapat hubungan antara motivasi belajar dengan nilai indeks prestasi pada mahasiswa Akademi Keperawatan Adi Husada Surabaya.

\section{SARAN}

1. Bagi mahasiswa, agar meningkatkan motivasi belajar dalam bidang yang sekarang sedang ditekun dan memiliki jadwal belajar yang teratur dapat memudahkan dalam mencerna setiap materi yang diterima,

2. Bagi institusi pendidikan, sebagai masukan untuk lebih memfasilitasi dan memperhatikan keperluan praktikum yang akan dilaksanakan oleh mahasiswa,

\section{DAFTAR PUSTAKA}

1. Nashar. (2004). Peranan Motivasi dan Kemampuan Awal dalam Kegiatan Pembelajaran. Jakarta: Delia Press.

2. Nasution, S. (1987). Berbagai Pendekatan dalam Proses Belajar Mengajar. Jakarta: Bina Aksara.

3. Poerwanto, Ngalim. (2007). Psikologi Pendidikan. Bandung: PT Rosda Karya.

4. Riduan. (2009). Belajar Mudah Penelitian untuk Guru-Karyawan dan Peneliti Pemula. Bandung:Alfabeta.

5. Sadirman. (2004). Interaksi dan Motivasi Belajar. Jakarta: PT Rineka Cipta.

6. Slamet. (2003). Belajar dan Faktorfaktor yang Mempengaruhinya. Jakarta: PT Rineka Cipta.

7. Wasty Soemanto. (2003). Psikologi Pendidikan. Malang: Rineka Cipta.

8. Winkel WS. (1997). Psikologi Pendidikan dan Evaluasi Belajar. Jakarta: Gramedia. 